\title{
Scientists' Lives and the History of Late Twentieth Century Life Sciences
}

Soraya de Chadarevian

James D. Watson 2007: Avoid Boring People. And Other Lessons from a Life in Science. Oxford: Oxford University Press, brosch., 362 S., $15,99 €$, ISBN-13: 978-0-199-54818-7.

J. Craig Venter 2007: A Life Decoded. My Genome: My Life. New York: Viking Penguin, geb., 400 S., 11,99 €, ISBN-13: 978-0-670-06358-1. (dt. Übersetzung, 2009. Entschlüsselt. Mein Genom, mein Leben. Frankfurt: S. Fischer, geb., 576 S., 24,95€, ISBN-13: 978-3-100-87030-8.)

Robert Olby 2009: Francis Crick. Hunter of Life's Secrets. New York: Cold Spring Harbor Laboratory Press, geb., 450 S., 32, $99 €$, ISBN13: 978-0-879-69798-3.

The three books, two autobiographies and one biography, record the lives of three of the most well-known and controversial figures of molecular biology. The protagonists hardly need introduction: Jim Watson and Francis Crick are famous for their part in the elucidation of the double helical structure of DNA which became the subject of Watson's best selling book The Double Helix (1968). Craig Venter first made headlines by competing with the publicly funded project to sequence the full human genome. More recently, he has been in the news for his genomic exploration of the world's oceans and for his claim of having synthesized bacterial life. Although clearly drawing on these public images, in the book-length accounts of their lives, the authors - biographers or autobiographers - aim to move beyond these restricted narratives and provide richer accounts of the people and the events that formed them.

Scientific biographies and autobiographies are a well-established genre. Science writers, journalists and professional historians as well as scientists 
engage in it, even if with slightly different aims. Publishers seem keen to include scientific biographies into their programs, although not all sell well. The biographical format seems well suited to bring science to broader audiences by providing a human dimension to what might seem like a daunting or arcane subject. In the history of science the biographical format has been the subject of animated debates, as the format may seem to reinforce a narrative around great (mostly male) scientists from which the field has tried to distance itself. Yet biographies are also seen as uniquely suited to address questions on the changing persona of the scientist and on the value of science in the life of its practitioners. They can provide insights into the conduct of science through the experience of the protagonists and move beyond the individual to address questions of politics, costume and culture (Terrall 2006). The question then will be how the three books under review respond to these claims and expectations and which new insights they provide into the history of the life sciences in the late twentieth century. Yet before we move to these questions it seems advisable to start by analyzing how the authors themselves present their projects and by briefly outlining their stories.

Watson has presented parts of his biography on other occasions. The racy, if highly controversial account of his collaboration with Crick during his stay at Cambridge in the early 1950s was followed by a decidedly less successful account of the years "after the double helix" (1953-1968) in Genes, Girls and Gamow (2001). In the present volume that covers his life in science "before middle life" or up to his departure from Harvard in 1976, Watson chooses to distill his life in fifteen sets of remembered lessons that he offers to aspiring young scientists as well as "to those on the top who do not want their leadership years to be an assemblage of opportunities gone astray" (preface). The lessons appear at the end of each chapter, which lead us from his childhood years to his undergraduate studies in Chicago, his graduate studies in genetics with Salvador Luria at the University of Illinois, his growing up in the phage group, his years abroad including his stay at Cambridge, his life as professor at Harvard, receiving and living with the Nobel Prize, and the drafting of the double helix story. The lessons are summarized again at the end of the book for easier reference. The most important lesson is the one that forms the book's title: "Avoid boring people". It is repeated at least twice. Other lessons range from the pedagogical ("college is for learning how to think"; "choose a young thesis adviser") and the collegial ("ask the dean only for what he can give") to the worldly ("use first names as soon as possible") and the trivial or profane ("buy, don't rent, a suit of tails"; "expect to put on weight after Stockholm"; "never dye your hair or use collagen"). So much good advice cannot but bore. How transferable the lessons from Watson's life are, is another question. After all, it is somewhat ironic that Watson, who has often been accused of lacking tact and manners, is proposing the manners he deployed to navigate academia for others to follow. Yet Watson sees his life "as an object lesson, if not quite an 
exemplary history of the making of a scientist" (preface). He builds his account on what he describes as the "first crack" at his papers that will eventually become available to the public, in paper and digital form, in the archives of Cold Spring Harbor Laboratory. Before other commentators or historians will have access to the material, Watson decided to have a go himself. Victor McElheny's "unauthorized biography" of Watson of 2003 is not mentioned with one word.

Craig Venter did not win the Nobel Prize (at least not yet). He is keenly aware of the pitfalls of writing autobiographies and starts off his own by listing weighty objections against engaging in this "self-indulgent" kind of exercise. Yet he is convinced that his story is worth telling as he had been fortunate to take part in "one of the greatest, most exciting, and, potentially, most beneficial scientific adventures of all time" (p. 1). The excitement is provided by the "impossible scientific quests" but also by "great rivalries and bitter disputes, and clashes of egos involving some of the biggest figures in biology" (p. 2) in which the hero of the story participated. Another aspect that distinguishes his autobiography from others is that it is the first to benefit from being accompanied by the full read out of its author's genetic code, leaving his life open to future interpretations (the author's DNA is not actually appended to the book - at least my copy did not come with a CD version of Venter's DNA sequence attached - rather the statement refers to Venter's controversial decision to use his own DNA as material for Celera Genomics' effort to sequence the full human genome. His genome, possibly the highest quality personal genome sequence currently available, can be accessed online and searched with the Human Reference Genome Browser). Indeed, text boxes interspersed in the running text offer pieces of insights into Venter's genetic read out or his "genetic autobiography" (p. 7). Sometimes these illuminate an aspect of the narrative, other times the information offered is rather random. In this way we learn, for instance, that Venter's DNA carries the genetic repeat DAT1 that is linked with ADHD (attention deficit/hyperactivity disorder) and may explain his unpromising school career. We hear about his Y chromosome's involvement with sex; that his genome carries an unusual sequence normally found in chimps as well as a gene linked to obesity and various genes linked to late-onset Alzheimer. Apart from his genes, Venter is marked by the grueling experience of serving in Vietnam that gave him drive and determination in life. While Venter intends to put the "sheer excitement" of the science he was involved in at the centre of his account, he also wants his life to serve as an inspiration of what one can achieve, against the odds. In this respect, his ambition is similar to Watson's. Tellingly, we learn that Watson's book The Double Helix made a strong impact on Venter. Looking back it appears to him that Watson and Crick were the "original bad boys of molecular biology" (p. 52), a role he himself would later assume when competing with the publicly funded human genome project, entering into commercial agreements and restricting access 
to sequence data. However, it is an image he tries to contradict by depicting himself as being exclusively involved in a lone crusade to push science forward at a fast pace rather than in pursuing political games as his many adversaries. Occasionally this required accepting private funds or entering into commercial agreements, but the aim was always to advance science for the benefit of humanity. The list of achievements speaks for itself: development of expressed sequence tags (EST) for gene identification; pioneering use of the whole genome shotgun approach to sequencing the first free-living organism, the bacterium Haemophilus influenzae; sequencing of the fruit fly, mouse and rat genome; sequencing of the full human genome in less time and for less cost than the publicly funded effort; inroads into cancer genomics; launch of the ocean genome project with the goal of sequencing all the microbes in the ocean in one go and assessing their genetic diversity; construction of a minimal viable artificial genome. The list also includes creating three institutions, starting with Celera Genomics, followed by the Institute for Genomic Research and, most recently, the J. Craig Venter Institute as well as the company Synthetic Genomics, Inc. When opposition to his research projects and the animosities that went with it became too hard to bear, Venter found relief and new resolve in equally brave sailing adventures. Their descriptions highlight the tough and adventurous spirit of the scientist and his endeavors. In narrating his life Venter strove for accuracy by checking the information against written sources - including James Shreeve's Genome Wars (2004) and John Sulston's and Georgina Ferry's The Common Thread (2002) on which he repeatedly relies - as well as engaging family, friends and colleagues to back up his own memory and provide additional perspectives on specific events. Yet above all he is seeking acceptance and recognition for his many hard won achievements.

Robert Olby's biography of Crick is itself a life's work. Although the project only matured in the 1990s, Olby's involvement with Crick goes back to the mid-1960s, when Olby contemplated writing a book on the discovery of the structure of DNA. He first met Crick personally in 1966 at a lecture the latter delivered in Oxford. Crick's announced lecture on "The Influence of Physics on Molecular Biology" turned into an absorbing and humorous account of Watson's and his work on the structure of DNA. The timing is relevant here, as by then Crick had read the first draft of Watson's manuscript on the subject that he so vehemently opposed. Crick encouraged Olby in his plan to write a scholarly book on the subject to counterbalance Watson's novel-like approach. He later provided the foreword for what became The Path to the Double Helix, published in 1974 by Olby. Around that time Olby also produced a first biographical essay on Crick (1970). Eventually Crick agreed to the idea of a full biography, provided it would not be published before his death (Matt Ridley's slimmer biography of Crick also only appeared after his death in 2006). I expect Crick also insisted it should be an intellectual biography. He closely read fourteen of the twenty-one chapters of the book and extensively discussed the 
outline of the remaining seven. Olby openly declares himself an admirer of Crick, but contends that admirers are not necessarily hagiographers. The book has the self-pronounced task to "flesh out [the] evolution of [Crick's] personality" and to set his achievements in the changing landscape of the biological sciences (p. xii). It begins with Crick hosting his Nobel Prize party and receiving the prize in Stockholm as well as his hostile reaction to Watson's book that made the pair more famous than the Nobel award. Olby justifies choosing this as the starting point of his account as the readers will meet Crick at a phase of his life they are already familiar with (quite in contrast, in the photograph of a rather nerdy looking twenty-year old Crick, holding some experimental physics paraphernalia in his hand, chosen as cover picture, it is hard to recognize any of his familiar features). The narrative then moves back to Crick's childhood in Northampton and from there follows a chronological and in its outlines well-known path leading from Crick's studies at University College London, to his war work as scientist (reconstructed in rich detail), his turn from physics to biological problems after the war, his central contributions to the making of molecular biology, his eventual move to the Salk Institute in La Jolla, California and his turn to the neurosciences in the mid1970s. Olby is rigorous in assembling and checking sources and scientific details and in this respect his book sets very high standards. Even in respect to such over-trodden areas as the double helix story, also informed readers will find some nuggets of new information, drawn from interviews or the newly available archival sources, including especially the Crick Papers at the Wellcome Library. The question we need to ask is, how successful the personal and the scientific are woven together in a way that they illuminate each other. Here I believe the answer is less clear. Olby successfully welds together Crick's personal and intellectual development - and perhaps this is all that can be asked from a scientific biography. At the same time large parts of Crick's personal life are only very sparingly alluded to, while the focus on personality at times seems at odds with the detailed explanations of scientific developments. More seriously perhaps, in his focus on Crick's intellectual development, Olby reaches back to an established narrative of the development of molecular biology that is not further illuminated or questioned. Here we come back to the general question posed at the beginning.

Reading the three biographies as a set, one is left rather exhausted by the confrontation with these three overbearing personalities. Is science a question of personalities? What role does personality play in late twentieth century life sciences? How does personality refer to the persona of the scientist? How does this persona change from the 1950s to 2000? Are Crick's systematic refusal of taking on institutional responsibilities, Watson's extensive promotion and lobbying for the new biology, and Venter's entrepreneurial style just personal traits or are these differences historically relevant? These are questions that historians can rightly ask, but to which the books provide at best indirect 
answers. If the value of scientific biographies is "that they return our focus on the place of human beings, with all their wonderful quirks and crankiness, in the development of the great human experience that is science" (Richards 2006: 305), then the three biographies have fulfilled their aim. Yet if the value of scientific biographies is to move beyond the individual and explore the cultural dynamics of science, then historians need to get working, building on the rich material Watson, Venter, Olby and other biographers of twentieth century life scientists have provided.

\section{Literature}

McElheny, Victor K., 2003. Watson and DNA: Making a Scientific Revolution. Cambridge, MA: Perseus Publishing.

Olby, Robert C., 1970. Francis Crick, DNA, and the Central Dogma. Daedalus, 99, 938-987.

Olby, Robert C., 1974. The Path to the Double Helix. London: Macmillan.

Richards, Joan L., 2006. Introduction: Fragmented Lives. Isis, 97, 302-305.

Ridley, Matt, 2006. Francis Crick: Discoverer of the Genetic Code. New York: Atlas Books.

Shreeve, James, 2004. The Genome War. How Craig Venter Tried to Capture the Code of Life and Save the World. New York: Knopf.

Sulston, John/Ferry, Georgina, 2002. The Common Thread. A Story of Science, Politics, Ethics and the Human Genome Project. London: Bantam Press.

Terrall, Mary, 2006. Biography as a Cultural History of Science. Isis, 97, 306-313.

Watson, James D., 1968. The Double Helix. A Personal Account of the Discovery of the Structure of $D N A$. New York: Weidenfeld and Nicolson.

Watson, James D., 2001. Genes, Girls and Gamow. Oxford/New York: Oxford University Press.

Soraya de Chadarevian

Department of History and Center for Society and Genetics

University of California Los Angeles

6265 Bunche Hall

Los Angeles CA 90095-1473

USA

E-Mail: chadarevian@history.ucla.edu 